\title{
Sea ice transport: a highly variable link between Arctic and North Atlantic
}

\author{
Michael Hilmer, Markus Harder and Peter Lemke \\ Institut für Meereskunde an der Universität Kiel, Germany
}

\begin{abstract}
The variability of the ice volume flux into the northeast Atlantic is investigated with an optimized dynamic-thermodynamic sea ice model using 40 years (19581997) of atmospheric forcing fields derived from the NCEP/ NCAR reanalysis project. The simulated sea ice export from the Arctic exhibits considerable interannual to decadal variability and is primarily a linear response to sea level pressure anomalies over Greenland and over the Barents and Kara Seas. Our model results suggest that ice export anomalies such as in 1968 which supposedly caused the so-called "Great Salinity Anomaly" in the northern North Atlantic are not unique but rather frequent events as part of the variability of the Arctic climate system.
\end{abstract}

\section{Introduction}

The thermohaline part of the global ocean circulation is primarily forced by freshwater fluxes at high latitudes, i.e. precipitation/evaporation, and melting/freezing of sea ice. Model studies of the thermohaline circulation (THC) indicate [e.g., Marotzke and Willebrand, 1991; Rahmstorf, 1995] that different equilibrium states of the THC exist, which are sensitive to changes in freshwater forcing. While freshwater intrusions acting over decadal time scales are necessary to wind down the THC completely, smaller freshwater pertubations can regionally shutdown the convection and therefore change the oceanic heat transport and North Atlantic climate [Rahmstorf, 1994]. An example of such a freshening event was the so-called "Great Salinity Anomaly" (GSA) in the northern North Atlantic in the late 1960s [Dickson et al., 1988]. A major cause of this anomaly is supposed to be excessive sea ice export from the Arctic [Aagaard and Carmack, 1989; Häkkinen, 1993]. To assess the variability of this freshwater flux, we investigate the simulated sea ice export from the Arctic into the North Atlantic using a 40-year integration of a dynamic-thermodynamic sea ice model.

\section{Results}

An optimized dynamic-thermodynamic sea ice model [Harder et al., 1998; Lemke et al., 1997] with a viscousplastic rheology is used. It is forced with daily fields of surface winds and temperatures for the period 19581997, derived from the National Center of Environmental Prediction/National Center of Atmospheric Research (NCEP/NCAR) reanalyses, which represent a consistent

Copyright 1998 by the American Geophysical Union.

Paper number 98GL52360.

0094-8534/98/98GL-52360\$05.00 data set without artificial "climate shifts" induced by changes in the data assimilation system [Kalnay et al., 1996]. The remaining forcing fields are prescribed as climatological means.

Figure 1 shows the long-term mean simulated ice thickness, net freezing rate and ice drift pattern. As indicated by the spatial distribution of the net freezing rate, sea ice is primarily produced near the Siberian shelves where the mean ice drift is offshore. Following the Transpolar Drift Stream (TPDS) the ice partially feeds the Beaufort Gyre whereas the remainder drifts into the northeast Atlantic, representing a large freshwater input after melting. Most of the southward drifting ice passes through Fram Strait. Time series of the simulated annual means of the Fram Strait ice export are shown in Figure 2a. The long term average amounts to $0.091 \mathrm{~Sv}$, or $2870 \mathrm{~km}^{3} /$ year. The standard deviation of the annual means represents about $20 \%$ of the long-term average. Differences between the annual mean exports in different years are as large as a factor of two, indicating the large variability of this flux. Spectral analysis of the time series reveals that a large part of the variance is apparent at periods of 6-7 years and that there is also enhanced variance at the decadal time-scale (12-14 years). The highest ice exports through Fram Strait occurred in 1958 and 1995 with nearly the same annual means of $0.128 \mathrm{~Sv}$. The 1995 maximum is also found in observations, which are available in Fram Strait since the late 1980s [Vinje et al., 1997].

To investigate the characteristic differences between the two events of highest export $(1968,1995)$, anomalies (i.e. deviations from the long-term mean shown in Fig. 1) of the sea ice drift pattern, the net freezing rate and the sea level pressure are displayed in Figures 3 and 4 . In 1968, the wind field, produced by an anomalous low centered over the Kara and Laptev Seas and an anomalous high north of Canadian Archipelago and north of Iceland, directed an enhanced TPDS from the Beaufort Sea/North Pole region to the Barents Sea (see Figure 3). This resulted in a large southward ice flow east of Spitzbergen, in addition to the export of very thick ice that passed through Fram Strait, leading to a large volume of melted ice within the Greenland/Iceland/Norwegian (GIN) Seas. This anomalous drift direction also caused an enhanced ice coverage in this area. The time series of the sea ice extent anomalies in the GIN Seas (Fig. 2b) shows an outstanding positive anomaly in 1968, which is also found in observations [Mysak and Manak, 1989]. In 1995, there was an anomalous low over the Barents and Kara Seas and higher than normal pressure near the North Pole (see Figure 4). This pattern of pressure anomalies is in general similar to that of 1968, but is rotated clockwise by about $45^{\circ}$. The anomalous wind field associated with this pressure distribution caused an enhancement of the TPDS that was directed from the East Siberian/Kara 


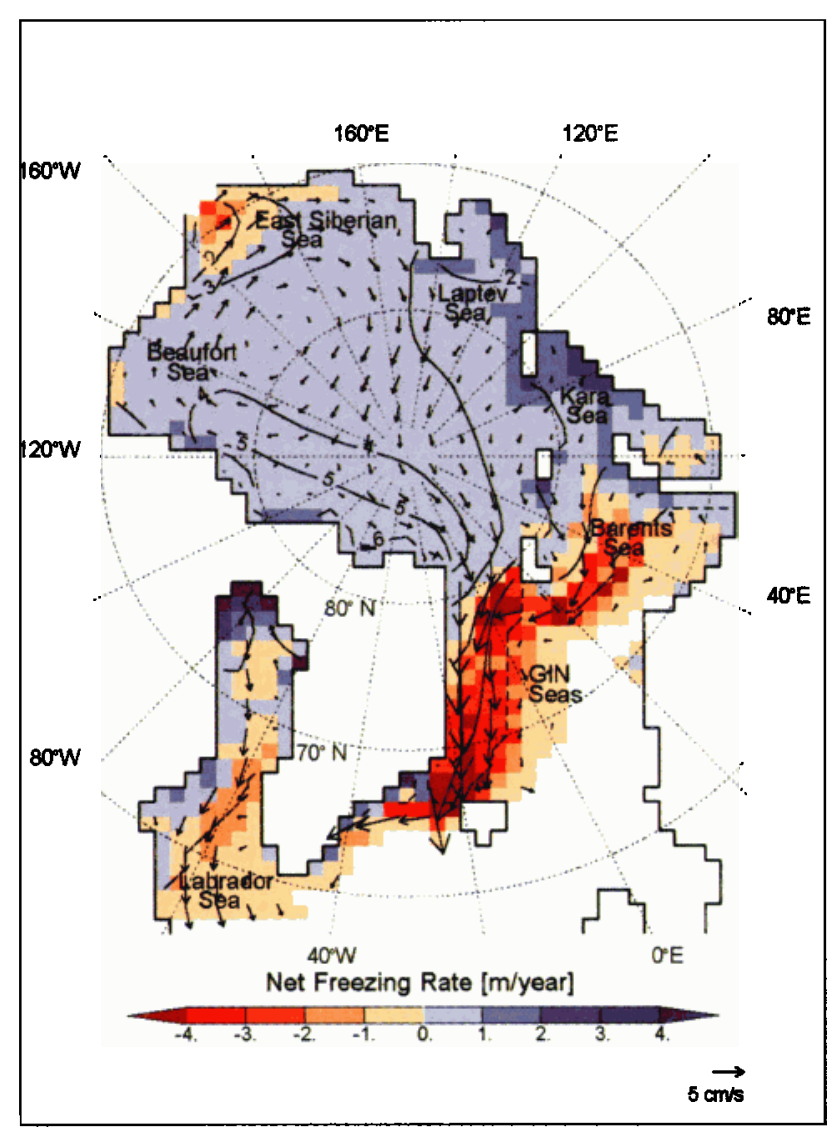

Figure 1. Mean conditions of the simulated Arctic ice cover for the period 1958-1997. The color shading displays net freezing rates (thermodynamic growth minus melt of sea ice in $\mathrm{m}$ /year) for each grid cell, and the arrows represent the ice drift vectors. Only every fourth arrow is drawn. Solid contour lines show the ice thickness (varying from 1 to $6 \mathrm{~m}$ ), and the dashed line indicates the ice edge (defined as an ice concentration of $\mathbf{1 5 \%}$ ).

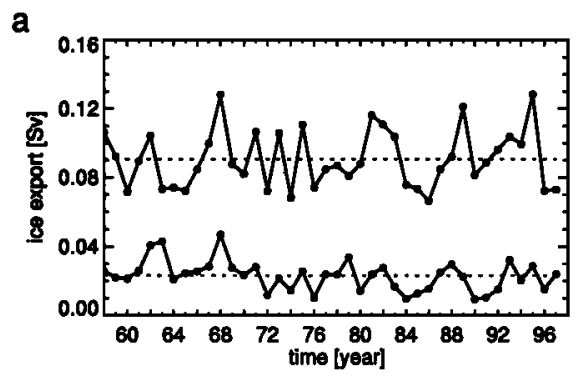

C

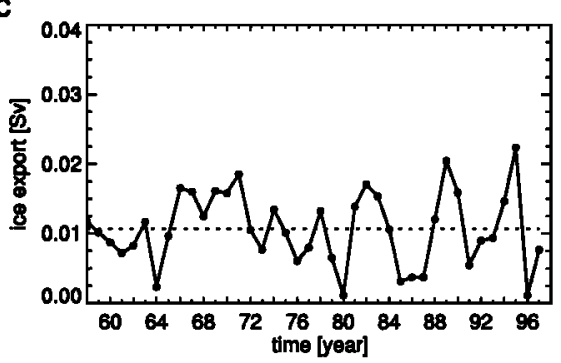

Seas to Fram Strait at this time. As a consequence, the annual mean southward drift speed in Fram Strait was higher than in 1968, while the transported ice was thinner and the ice extent anomaly in the GIN Seas smaller. Due to the high drift speed within the East Greenland Current, the time series of the ice export through Denmark Strait (Fig. 2c) shows a maximum anomaly of $0.012 \mathrm{~Sv}$ in 1995 , which is as large as the mean value. Thus, in 1995 a large part of the exported sea ice from the Arctic melted within the North Atlantic southwest of Iceland, while in 1968 there was an anomalous melting within the center of the GIN Seas, as seen from a comparison of the net freezing rate anomalies in Figures 3 and 4.

Although sea ice export east of Spitzbergen is much smaller in magnitude than through Fram Strait in most years (Fig. 2a), it is important to consider both exports together for studies of the variability of the net freshwater input into the GIN Seas. The time series of the annual means of this total export (the sum of the two curves in Fig. 2a) shows one outstanding positive anomaly in 1968, accounting for an ice volume export $1900 \mathrm{~km}^{3} /$ year larger than the long-term mean of $3600 \mathrm{~km}^{3} /$ year. Taking into account the lower density and salinity of sea ice as compared to sea water, this ice export anomaly represents a freshwater excess of about $1500 \mathrm{~km}^{3} /$ year. This value roughly agrees with the estimated $2000 \mathrm{~km}^{3} /$ year of freshwater excess associated with the GSA [Dickson et al., 1988; Aagaard and Carmack, 1989], considering some additional export of low salinity water in the surface layer of the East Greenland Current. The anomaly of the ice volume export into the GIN Seas in 1995 amounted to $1350 \mathrm{~km}^{3}$ /year, i.e., $70 \%$ of the 1968 anomaly. Considering the net import of sea ice into the GIN Seas (Fig. 2d), the dominant role of the late 1960s in the freshwater budget of this region becomes obvious.

Figure 5 displays the averaged field of pressure anomalies associated with enhanced sea ice exports, derived by a linear regression of the anomalies of total ice export upon sea level pressure anomalies at each grid point. A significance

b

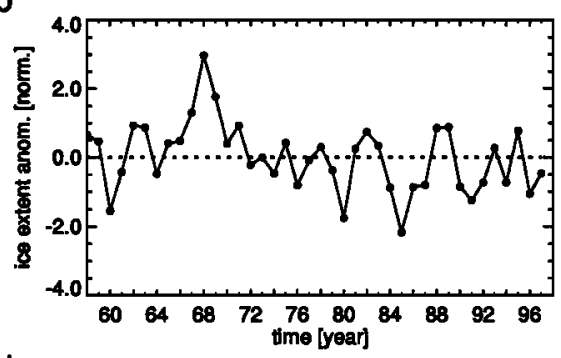

d

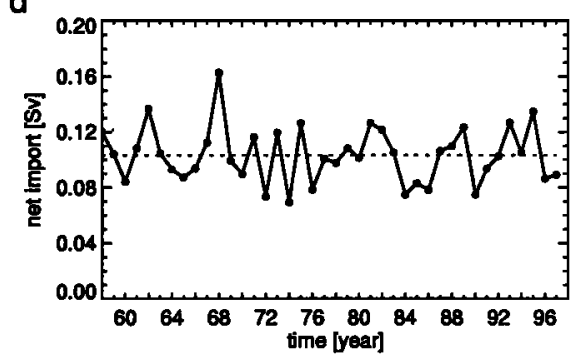

Figure 2. Annual means of a) southward sea ice volume transport through Fram Strait (upper curve) and southward transport east of Spitzbergen (lower curve), b) normalized anomalies of the ice covered area in the GIN Seas, c) sea ice transport through Denmark Strait and d) the net import of sea ice of the GIN Seas (sum of the two exports shown in Fig. 2a minus the export shown in Fig. 2c). The dotted lines in each plot indicate the long-term mean value. 


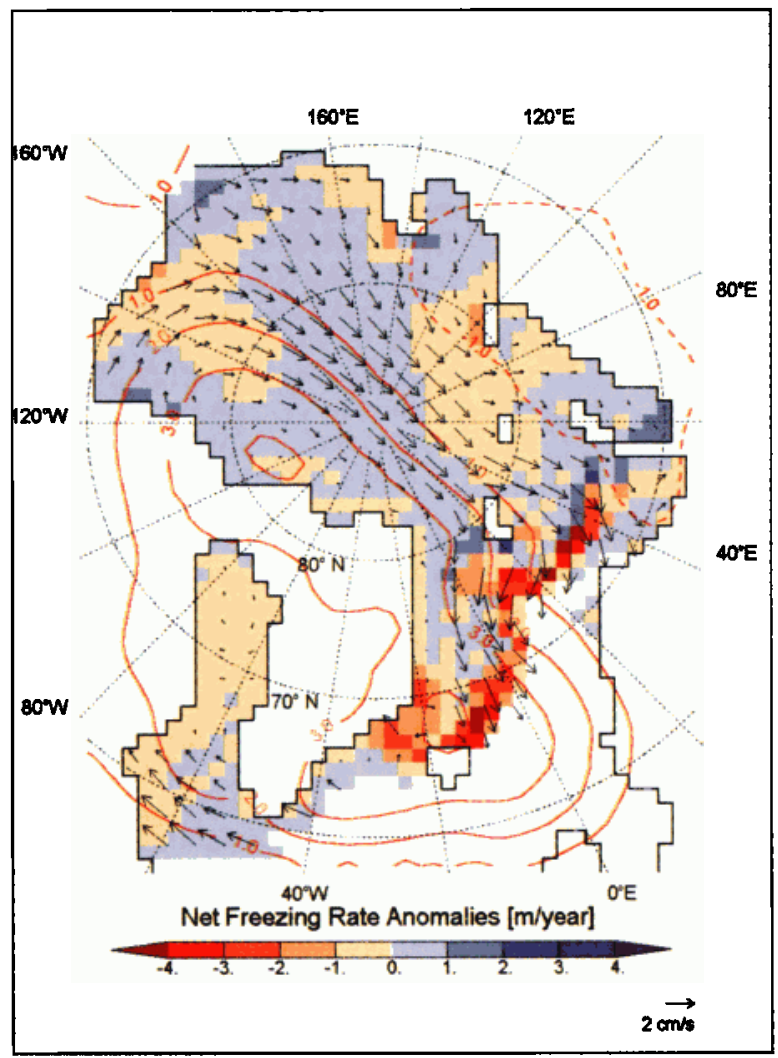

Figure 3. Annual mean anomalies in $\mathbf{1 9 6 8}$ of net freezing rate (color shaded), ice drift (arrows) and sea level pressure (contour lines) as departures from the long-term mean.

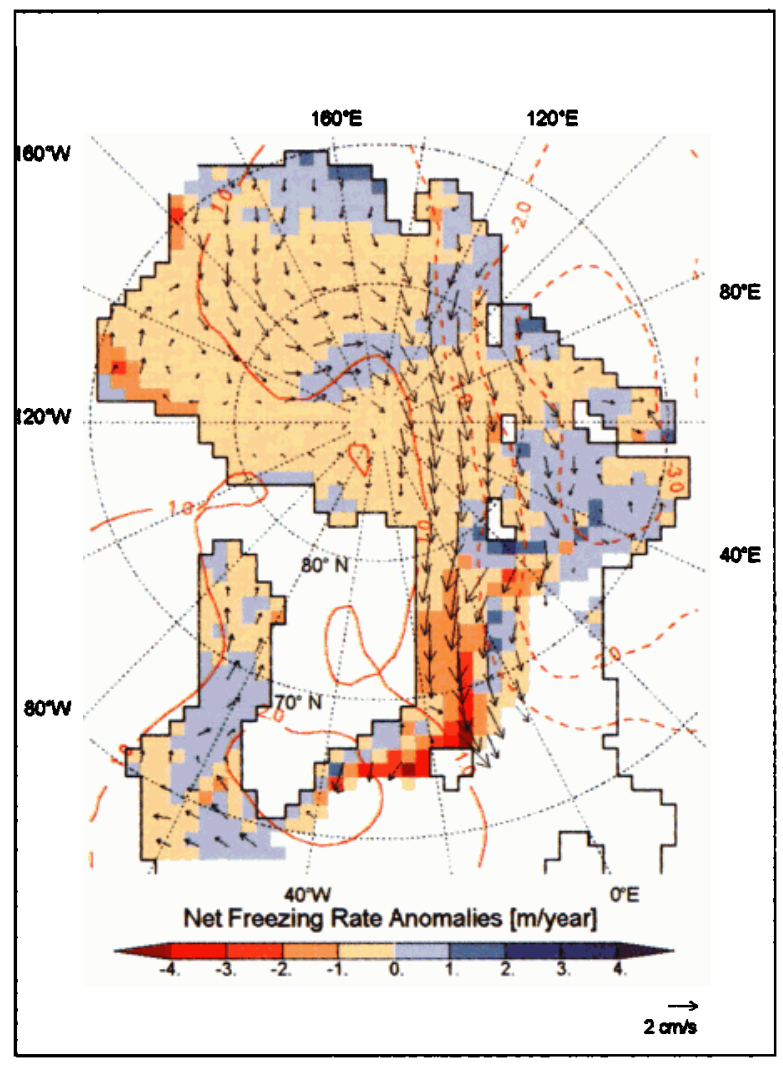

Figure 4. Same as Figure 3 but for 1995.

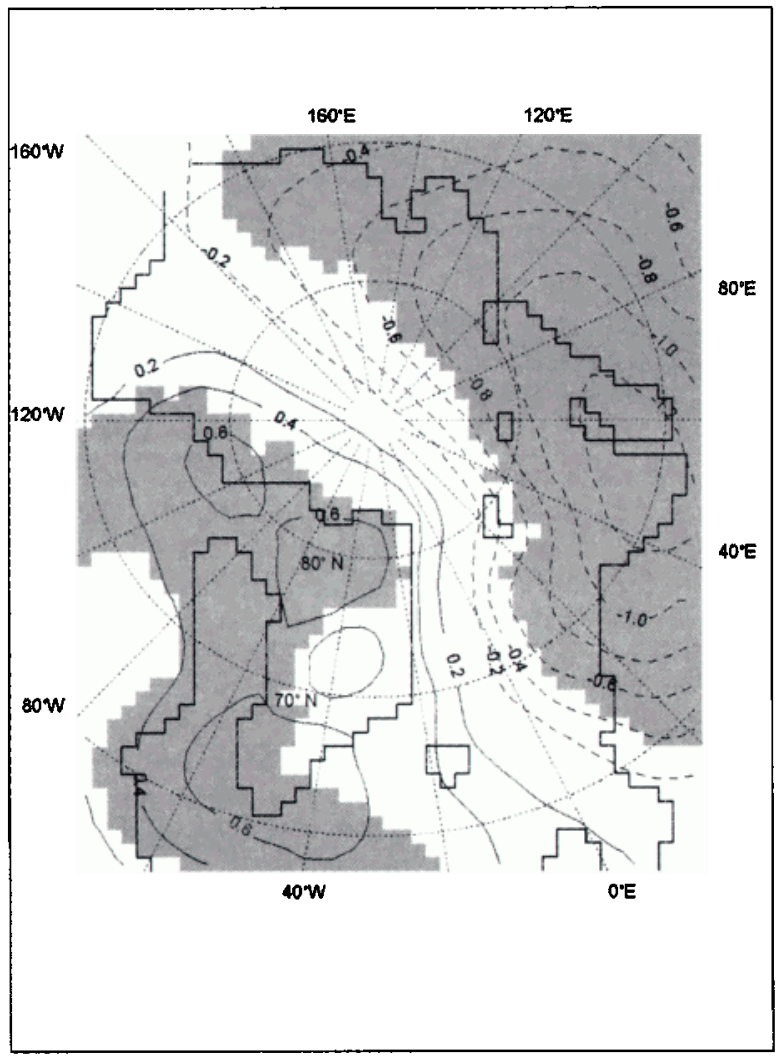

Figure 5. Average atmospheric pressure field associated with high total sea ice exports into the GIN Seas. The regression of annual sea level pressure anomalies at each grid point upon the time series of anomalies of the total ice volume export into the GIN Seas was computed. Prior to the regression analysis, the anomalous ice export time series was normalized with its standard deviation. Thus, the pattern shows the mean sea level pressure anomaly field (in $\mathrm{hPa}$ ) associated with an ice export anomaly of one standard deviation above zero. The slope parameter of the regressions was tested to be different from zero on the $95 \%$-confidence level. Statistically significant values are shaded.

test reveals that the total ice export into the GIN Seas is in general a linear response to both an anomalous low over the Barents and Kara Seas and an anomalous high over Greenland. Comparing the sea level pressure anomalies in 1968 and 1995 with this mean anomaly pattern, it follows that these years exhibit extreme states in both the orientation and magnitude of the centers of action.

\section{Discussion}

Our 40-year simulation of the Arctic ice cover reveals that the sea ice volume export from the Arctic into the North Atlantic exhibits considerable interannual to decadal variability, mainly as a response to atmospheric circulation anomalies over Greenland and over the Barents and Kara Seas. The highest export occurred in 1968 and was, as a consequence of the anomalous direction of the Transpolar Drift Stream, associated with the maximum sea ice extent in the GIN Seas within the simulated period 1958-1997. To properly describe the freshwater budget of the GIN Seas 
it is necessary to consider the southward transport of sea ice east of Spitzbergen in addition to the transport through Fram Strait. Although the Fram Strait ice export in 1995 has nearly the same value as in 1968 , the total ice export of this year accounts only for $70 \%$ of the 1968 maximum. However, the 1995 anomaly is $40 \%$ larger than the long-term mean and thus may have left a recent freshwater signal in the upper layers of the northern North Atlantic.

A circulation of the GSA around the subpolar gyre was deduced [Dickson et al., 1988] from salinity sections taken in the North Atlantic in the 1970s. Low salinities in the GIN Seas in 1981/82 were interpreted as the return of the GSA [Dickson et al., 1988]. Our simulation shows an enhanced total ice export from the Arctic into the GIN Seas in these years (Fig. 2c). This suggests that the "return of the GSA" may have been the formation of a new low salinity signal.

Studies using observational data provide evidence that freshwater anomalies induced by sea ice anomalies in the GIN Seas can even effect the ice coverage in the Labrador Sea some years later [Mysak and Manak, 1989]. Jung et al. [personal communication, 1998] propose a mechanism in which sea ice anomalies in the Labrador Sea can affect the climate system further downstream. The sea level pressure pattern involved in their decadal mode shows a pronounced high pressure anomaly over south Greenland as one centre of action. This agrees well with the associated correlation pattern which we obtain when considering low-frequency variability of the total ice export (i.e. regression of low-pass filtered time series; 5-year running mean).

Our model results suggest that the sea ice export from the Arctic represents an effective mechanism of transferring variability from the atmosphere into the ocean and, therefore, participates in North Atlantic climate fluctuations.

Acknowledgments. This is a contribution of Sonderforschungsbereich 460 "Dynamik thermohaliner Zirkulationsschwankungen" at the University of Kiel supported by the Deutsche Forschungsgemeinschaft. NCEP/NCAR Reanalysis data were provided through the NOAA Climate Diagnostics Center (http://www.cdc.noaa.gov/).

\section{References}

Aagaard, K. and E.C. Carmack, The role of sea ice and other fresh water in the Arctic circulation. J. Geophys. Res., 94(C10), 14485- 14498, (1989)

Dickson, R.R., J. Meinke, S.A. Malmberg and A.J. Lee, The "Great Salinity Anomaly" in the northern North Atlantic 1968-1982. Progress in Oceanography, 20, 103-151, (1988)

Häkkinen, S., An Arctic source for the Great Salinity Anomaly: A simulation of the Arctic ice-ocean system for 1955-1975. J. Geophys. Res., 98(C9), 16397-16410, (1993)

Harder, M., P. Lemke and M. Hilmer, Simulation of sea ice transport through Fram Strait: Natural variability and sensitivity to forcing. J. Geophys. Res., 103(C3), 5595-5606, (1998)

Kalnay, E., M. Kanamitsu, R. Kistler, W. Collins, D. Deaven, L. Gandin, M. Iredell, S. Saha, G. White, J. Woollen, Y. Zhu, M. Chelliah, W. Ebisuzaki, W. Higgins, J. Janowiak, K.C. Mo, C. Ropelewski, J. Wang, A. Leetmaa, R. Reynolds, R. Jenne, and D. Joseph, The NCEP/NCAR 40-Year Reanalysis Project., Bull. Amer. Meteor. Soc., 7\%, No. 3, 437- -470, (1996)

Lemke, P., W.D. Hibler, G. Flato, M. Harder and M. Kreyscher, On the improvement of sea-ice models for climate simulations: the Sea Ice Model Intercomparison Project. Ann. Glaciol., 25, 183-187, (1997)

Marotzke, J. and J. Willebrand, Multiple Equilibria of the Global Thermohaline Circulation. J. Phys. Oceanogr., 21, 1372-1385, (1991)

Mysak, L.A. and D.K. Manak, Arctic sea-ice extent and anomalies, 1953-1984. Atmosphere-Ocean, 27, 376-405, (1989)

Rahmstorf, S., Rapid climate transitions in a coupled ocean- atmosphere model. Nature, 372, 82-85, (1994)

Rahmstorf, S., Bifurcations of the Atlantic thermohaline circulation in response to changes in the hydrological cycle. Nature, 378, 145-149, (1995)

Vinje, T., N. Nordlund and $\AA$. Kvambekk, Monitoring ice thickness in Fram Strait. J. Geophys. Res., 103(C5), 10437-10450, (1997)

M.Hilmer, M.Harder and P.Lemke, Institut für Meereskunde an der Universität Kiel, Düsternbrooker Weg 20, D-24105 Kiel, Germany(e-mail: mhilmer@ifm.uni-kiel.de)

(Received April 18, 1998; revised June 5, 1998; accepted June 24, 1998.) 